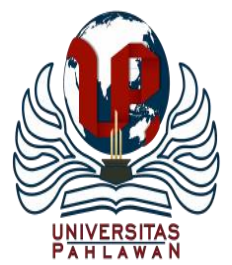

Edukatif : Jurnal Ilmu Pendidikan Volume 3 Nomor 4 Tahun 2021 Halm 1191 - 1198

EDUKATIF: JURNAL ILMU PENDIDIKAN

Research \& Learning in Education

https:/ledukatif.org/index.php/edukatif/index

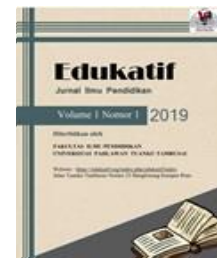

\title{
Identifikasi Mikonsepsi Siswa Menengah Atas (SMA) Pada Pembelajaran Kimia Materi Redoks dan Elektrokimia : Studi Literatur
}

\author{
Nindy Aulia Nisa ${ }^{1 凶}$, Zonalia Fitriza ${ }^{2}$ \\ Universitas Negeri Padang, Indonesia ${ }^{1,2}$ \\ E-mail : nindyaulia61@gmail.com¹, zonaliafitriza@gmail.com²
}

\begin{abstract}
Abstrak
Tujuan dari penelitian ini ialah untuk mengidentifikasi miskonsepsi siswa pada materi redoks dan elektrokimia pada siswa menengah atas. Materi ini terdiri dari beberapa sub topik yaitu reaksi redoks, sel volta, korosi, dan sel elektrolisis. Jenis penelitian yang digunakan yaitu penelitian kepustakaan (library research) dengan pendekatan semi sistematis menggunakan data sekunder. Data sekunder yang diperoleh dari beberapa database kemudian dianalisis dengan teknik analisa Miles dan Huberman. Prosedur penelitian dimulai dari merancang ulasan dengan memilah literature yang terkait, melakukan tinjauan dengan membaca literature dari berbagai sumber, menganalisis data untuk memperoleh informasi yang diperlukan, dan menulis ulasan yang sesuai dengan topik yang berkaitan dengan penelitian. Berdasarkan hasil studi kepustakaan diperoleh bahwa miskonsepsi yang terjadi pada materi redoks dan elektrokimia diantaranya saat menentukan aliran arus listrik pada sel galvani, potensial sel, elektrode pada sel galvani dan elektrolisis, produk/ hasil dari elektrolisis, faktor faktor yang menyebabkan terjadinya peristiwa korosi, cara mencegah terjadinya korosi dan menyetarakan suatu persamaan reaksi.
\end{abstract}

Kata Kunci: Miskonsepsi, Redoks, Elektrokimia, Studi Kepustakaan.

\begin{abstract}
The aim of this research is to identify students misconceptions related to redox and electrochemistry senior high school students. This material consists of several sub topics such as redox reactions, voltaic cells, corrosion, and electrolysis cells. The type of this research is library research using semi-systematic review type using secondary data. Secondary data obtained from the various database, then it analyzed using the Miles and Huberman analysis techniques. The research procedure starts from review by sorting related literature, conducting a review by reading literature from various sources, analyzing, and writing the review that relevant with topic in this research. Based on the results of the library research, it's find various misconceptions that occur in redox and electrochemical including the flow of electric current in galvanic cells, cell potential, electrodes on voltaic cells and electrolysis, electrolysis products, factors that cause corrosion, prevention of corrosion and balance the reaction equation.
\end{abstract}

Keywords: Misconception, Redox, Electrochemistry, Library Research.

Copyright (c) 2021 Nindy Aulia Nisa, Zonalia Fitriza

$\triangle$ Corresponding author

Email : nindyaulia61@gmail.com

DOI : https://doi.org/10.31004/edukatif.v3i4.516

ISSN 2656-8063 (Media Cetak)

ISSN 2656-8071 (Media Online)

Edukatif : Jurnal Ilmu Pendidikan Vol 3 No 4 Tahun 2021 p-ISSN 2656-8063 e-ISSN 2656-8071 
1192 Identifikasi Mikonsepsi Siswa Menengah Atas (SMA) Pada Pembelajaran Kimia Materi Redoks dan Elektrokimia : Studi Literatur - Nindy Aulia Nisa, Zonalia Fitriza

DOI: https://doi.org/10.31004/edukatif.v3i4.516

\section{PENDAHULUAN}

Proses pembelajaran kurikulum 2013 berbasis saintifik terdiri atas beberapa kegiatan diantaranya mengamati, merumuskan masalah dan hipotesis, mengumpulkan dan mengolah data, serta menarik kesimpulan (Kemendikbud, 2014). Kegiatan di atas diharapkan dapat meningkatkan kemampuan berpikir siswa dalam menyelesaikan suatu persoalan yang diberikan secara sistematik dengan harapan siswa bisa memahami materi yang diajarkan dengan sebaik mungkin (Hosnan, 2014). Hal ini dapat membantu siswa dalam menguasai materi secara tuntas (mastery learning) dengan adanya dukungan kondisi yang tepat. Kelebihan dari pembelajaran tuntas yaitu, pembelajaran tuntas sangat efektif dan memiliki retensi atau daya tahan yang lama saat memahami konsep yang diajarkan, belajar siswa secara keseluruhan menjadi lebih efisien dan menimbulkan sifat positif seperti rasa ingin tahu yang besar, percaya diri, bekerja secara kooperatif dan lainnya.

Tolak ukur yang digunakan dalam belajar tuntas (mastery learning) adalah tingkat kemampuan per tiap siswa, bukan perkelas. Siswa yang mampu mencapai standar kompetensi dapat melanjutkan ke materi berikutnya, sedangkan siswa yang belum mencapai standar kompetensi akan melakukan program perbaikan agar menguasai materi tersebut sepenuhnya. Instrumen tes yang digunakan hendaknya menggunakan tes diagnostik yang dapat berupa tes pilihan ganda, pilihan ganda beralasan, esai terbuka atau esai tertutup. Instrumen tes tersebut disusun berdasarkan indikator, sehingga siswa dapat mengetahui kesulitan yang ia alami sendiri dan guru dapat segera menindak lanjuti kesulitan dan miskonsepsi siswa. Miskonsepsi yang terjadi pada siswa dapat disebabkan oleh beberapa hal seperti, dari cara guru saat mengajar, buku teks yang digunakan sebagai acuan ataupun dari diri siswa itu sendiri. Siswa yang mengalami miskonsepsi yakin dengan pemahaman konsep yang ia miliki meskipun pemahaman yang ia miliki tidak sesuai secara ilmiah, berbeda dengan siswa yang tidak paham konsep sama sekali, ia tidak memiliki pengetahuan/konsep dasar terkait materi yang ia pelajari. Konsep dalam kimia bersifat berurut dan berjenjang, apabila mengalami kesulitan pada konsep dasar tentunya akan mempersulit siswa dalam memahami konsep yang lebih kompleks. Siswa menggunakan pengetahuan dasar yang ia miliki untuk mengevaluasi pengetahuan baru yang ia peroleh, jika pengetahuan baru yang ia dapatkan konsisten dengan pengetahuan dasar yang dimiliki maka akan mudah untuk menggabungkan konsep konsep dasar menjadi konsep yang lebih kompleks, namun sebaliknya jika pengetahuan baru yang ia peroleh bertentangan dengan pengetahuan dasar yang ia miliki maka akan mempersulit siswa memahami konsep berikutnya yang lebih kompleks (Fitriza et al., 2020).

Salah satu materi kimia yang berpotensi mengalami miskonsepsi berdasarkan hasil dari beberapa penelitian yaitu pada materi redoks dan elektrokimia. Hal ini dibuktikan dengan penelitian yang dilakukan oleh (Rahayu et al., 2011) ditemukan hanya 44\% siswa Indonesia yang memahami konsep - konsep pada materi tersebut, dikarenakan $84 \%$ dari konsep yang terdapat pada materi redoks dan elektrokimia sulit dipahami. Beberapa peneliti juga menemukan hal serupa, kesalahpahaman yang dialami siswa pada materi tersebut umumnya mengenai prediksi reaksi kimia yang terjadi pada suatu rangkaian sel volta berdasarkan data potensial reduksi standar yang diberikan, reaksi reduksi dan oksidasi yang terjadi pada sel galvani dan elektolisis, produk yang dihasilkan pada sel elektrolisis, kesulitan saat memvisualisasikan pergerakan elektron, saat menyetarakan persamaan kimia dan lain lain. Sehingga pada materi redoks dan elektrokimia memerlukan pemahaman mendalam karena ada keterkaitan antara konsep kimia dan perhitungan matematika yang merupakan materi prasyarat untuk materi elektrokimia (Yulianingtyas et al., 2017).

Materi redoks elektrokimia terdiri dari konsep abstrak yang melibatkan tiga representasi untuk memahami dan menganalisa suatu fenomena yang diberikan. Miniminya pengetahuan prasyarat, interpretasi bahasa siswa, kecendrungan siswa menghafal konsep dan rumus daripada memahami dan menganalisa suatu masalah, dan penggunaan bahasa buku yang tidak sesuai dalam menjelaskan konsep kimia dapat menyebabkan terjadi nya miskonsepsi pada materi redoks dan elektrokimia. Miskonsepsi yang dialami oleh 
siswa dapat mempengaruhi proses pemahaman konsep dan hasil belajar siswa, oleh sebab itu miskonsepsi harus segera diidentifikasi untuk membantu siswa memperbaiki konsep konsep tersebut. Terutama pada materi redoks dan elektrokimia yang merupakan satu materi kimia yang sering mengalami miskonsepsi. Penyusunan artikel ini bertujuan untuk mengetahui berbagai macam kesalahpahaman atau miskonsepsi yang dialami siswa pada materi redoks dan elektrokimia berdasarkan hasil penelitian sebelumnya agar dapat dijadikan acuan bagi guru untuk menyusun strategi pada proses pembelajaran sehingga terjadinya miskonsepsi dapat diminimalisir.

\section{METODE PENELITIAN}

Jenis penelitian yang penulis gunakan adalah penelitian kepustakaan dengan metode mengumpulkan data, membaca, mencatat dan mengolah data data tersebut tanpa melakukan riset lapangan (Mestika, 2004). jenis tinjuan literatur yang digunakan adalah pendekatan semi sistematis untuk mengidentifikasi dan memahami beberapa penelitian yang berkaitan dengan topik yang diteliti dalam cakupan yang luas(Snyder, 2019). Hal ini bertujuan untuk mengidentifikasi miskonsepsi pada materi redoks dan elektrokimia.

Sumber data yang digunakan berupa data sekunder yang diperoleh dari beberapa jurnal yang diambil dari situs database seperti google scholar, research gate, taylor \& francis online, dan science direct. Kemudian data data yang diperoleh kemudian dianalisa dengan cara mereduksi data, menyajikan data, dan menarik kesimpulan dengan teknik analisa Miles \& Huberman. Dalam mengidentifikasi miskonsepsi pada materi redoks dan elektrokimia dikelompokkan menjadi empat bagian berdasarkan sub topik yaitu redoks, sel volta, korosi dan sel elektrolosis.

Penelitian ini melalui empat tahapan sebagai berikut: 1) merancang ulasan, pada tahap ini mencari dan memilih literature yang sesuai dengan topik yang akan diteliti, 2) melakukan tinjauan dengan membaca literature yang relevan dan dapat mewakili subjek penelitian, 3) menganalisis, pada tahapan ini literatur yang relevan kemudian dianalisis untuk memperoleh informasi berupa topik, pengarang, tahun penerbit, jenis penelitian serta hasil penelitian, 4) Menulis ulasan sesuai dengan topic penelitian(Snyder, 2019).

\section{HASIL DAN PEMBAHASAN PENELITIAN}

Kesalahan yang terjadi pada siswa dalam memahami suatu konsep yang tidak sesuai secara ilmiah disebut dengan miskonsepsi (Treagust, 2006). Miskonsepsi siswa tidak lepas dari adanya kesalahan berupa kesalahan konsep, konsep yang tidak akurat, kekacauan konsep serta hubungan hirarkis konsep yang tidak tepat dapat menimbulkan miskonsepsi (Fowler, T. W., \& Bou Jaoude, 1987).Terjadinya miskonsepsi pada siswa akan menghambat siswa dalam menerima pengetahuan yang baru sehingga dapat menghalangi siswa dalam mencapai keberhasilan dalam proses pembelajaran (Artiawati et al., 2018).

Materi kimia yang memiliki konsep yang kompleks sehingga berpotensi menimbulkan miskonsepsi yang menyebabkan siswa kesulitan untuk memahami konsep pada materi tersebut, salah satunya adalah pada materi redoks dan elektrokimia. Materi redoks dan elektrokimia yang terdiri dari 4 sub topik yaitu redoks, sel volta, korosi dan elektrolisis. Artikel ini membahas mengenai miskonsepsi siswa pada materi redoks dan elektrokimia berdasarkan hasil analisis literatur yang terdiri dari gabungan 20 artikel yang diterbitkan pada jurnal nasional dan internasional serta proceeding internasional mengenai miskonsepsi yang terjadi pada materi redoks dan elektrokimia. Ditemukan banyak miskonsepsi pada materi tersebut diantaranya aliran arus listrik pada sel galvani, potensial sel, elektrode pada sel volta dan elektrolisis, produk dari elektrolisis, faktor penyebab terjadinya korosi, pencegahan korosi dan penyetaraan persamaan reaksi. 
Analisis dari beberapa gabungan literatur untuk mengidentifikasi miskonsepsi yang dialami oleh siswa pada materi redoks dan elektrokimia dapat dilihat pada Gambar 1 yang dibagi menjadi menjadi empat bagian besar yaitu mikonsepsi pada sub topik redoks, sel volta, korosi dan sel elektrolisis.

\section{Sel Volta}

- $\quad$ Elektron lepas dari katoda ke dalam larutan kemudian bergerak ke anode melalui jembatan garam untuk melengkapi sirkuit (Asnawi et al., 2017; Pamela J. Garnett \& Treagust, 1992)

- Dalam larutan, elektron bergerak tanpa bantuan dari ion-ion (Sanger \& Greenbowe, 1997a, 1997b)

- Dalam larutan, ion bergerak dari satu ion ke ion yang lain (Sanger \& Greenbowe, 1997b)

- Harga $E^{\circ}$ yang lebih positif dalam tabel potensial reduksi standar bertindak sebagai anode (Pamela J. Garnett \& Treagust, 1992; Pamela J. Garnett et al., 1995)

- Tempat terjadinya reaksi pelepasan elektron disebut katode (Schmidt et al., 2007)

- Potensial sel adalah penambahan potensial reduksi standar pada masing masing elektrode (Sanger \& Greenbowe, 1997a)

- Anode dan katode dapat diidentifikasi berdasarkan penempatan fisik setengah sel (Bakar \& Mukhtar, 2011; Dindar et al., 2010; Özkaya, A. L. İ., Üce, M. U. S. A., \& Sahin, 2003)

- $\quad$ Elektroda yang mempunyai potensial reduksi berharga positif lebih mudah mengalami oksidasi dibandingkan elektrode hidrogen standar (Asnawi et al., 2017)

- Tidak dapat terjadi reaksi spontan apabila kedua elektroda pada sel volta memiliki potensial reduksi standar berharga negatif (Asnawi et al., 2017)

- Data potensial reduksi standar dari logam disusun berdasarkan penurunan kereaktifannya(Asih et al., 2020)

- transfer elektron terjadi pada jembatan garam(Huddle \& White, 2000; A. N. Ogude \& Bradley, 1994)

- $\quad$ kegunaan jembatan garam untuk menyuplai elektron (Dindar et al., 2010)

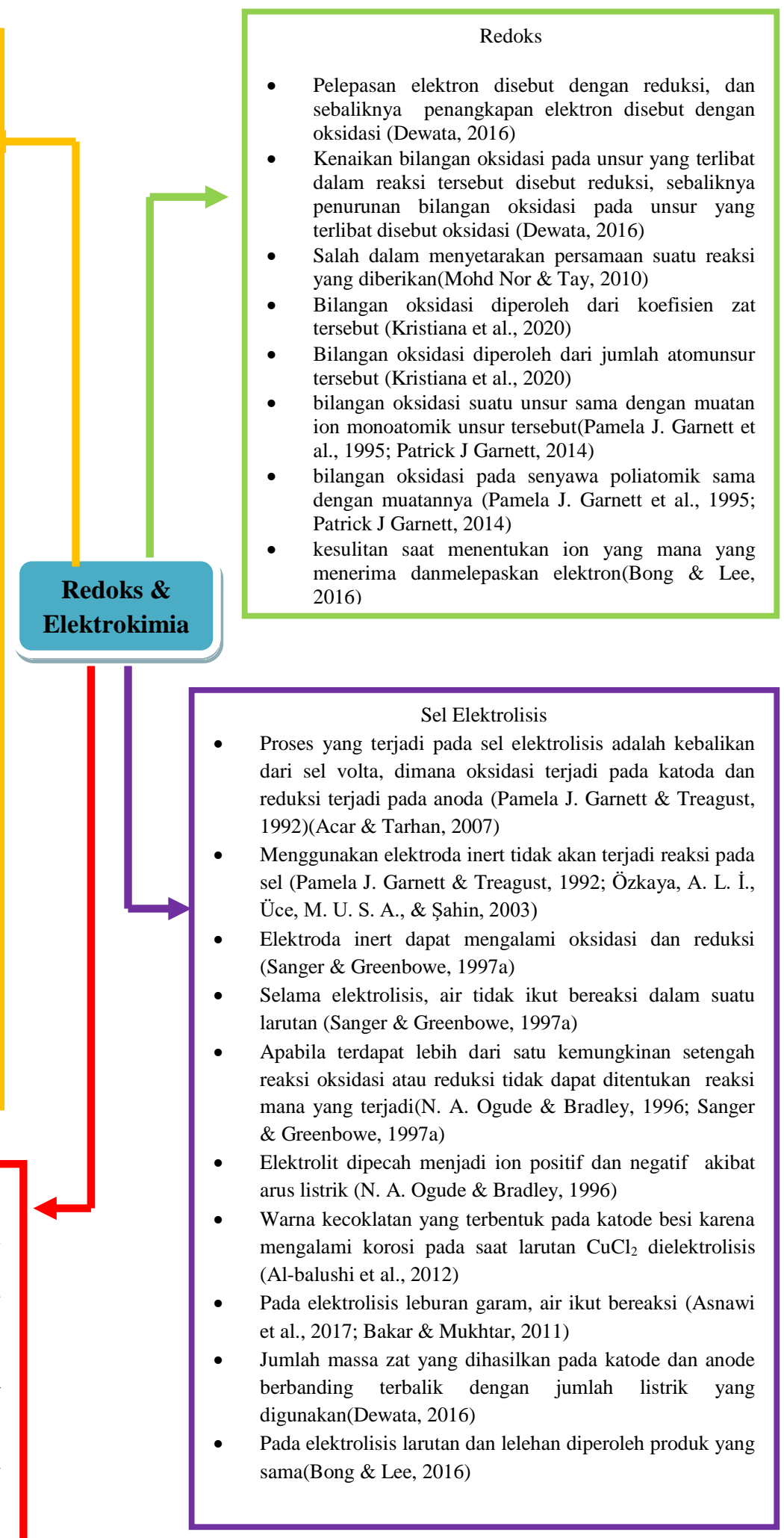

Gambar 1. Identifikasi miskonsepsi yang dialami siswa pada materi redoks dan elektrokimia 
Pada sub topik redoks, siswa ditemukan banyak mengalami miskonsepsi ketika menyetarakan persamaan reaksi, seperti saat menentukan bilangan oksidasi, menentukan ion mana yang melepas dan menangkap elektron serta konsep dasar dari reduksi dan oksidasi berdasarkan konsep melepas atau mengikat elektron, penurunan atau kenaikan bilangan bilangan oksidasi ${ }^{[16-21]}$. Reaksi redoks merupakan konsep dasar dari elektrokimia, apabila mengalami miskonsepsi maka akan siswa akan sulit untuk memahami materi berikutnya seperti sel volta, korosi dan sel elektrolisis(Chang, 2005).

Pada sub topik sel volta, terdapat berbagai miskonsepsi yang teridentifikasi, pertama mengenai arus listrik yang terjadi pada sel volta ketika menentukan dari mana arah arus listrik yang terjadi pada sel volta, siswa hendaknya dapat menentukan elektroda yang bertindak sebagai anoda dan katoda terlebih dahulu. Namun, pada tahap ini siswa mengalami kesalahpahaman konsep seperti 1) anode dan katode ditentukan berdasarkan penempatan fisik setengah selnya, hal ini dikarenakan pada setiap buku teks anoda digambarkan di sebelah kiri dan katoda di sebelah kanan sehingga siswa menentukan elektroda yang bertindak sebagai anoda dan katoda berdasarkan penempatannya bukan berdasarkan potensial reduksi elektroda (Özkaya, A. L. İ., Üce, M. U. S. A., \& Şahin, 2003), 2) elektroda yang mengalami oksidasi adalah elektroda yang bernilai positif dibandingkan elektroda hidrogen standar, hal ini dapat terjadi karena terjadi kesalahpahaman konsep saat mengurutkan data potensial reduksi standar berdasarkan daya kereaktifannya (Pamela J. Garnett \& Treagust, 1992), 3) katode merupakan tempat terjadinya reaksi pelepasan elektron, seharusnya katoda merupakan tempat terjadinya penangkapan elektron karena potensial reduksi elektrodanya lebih besar dibandingkan anoda sehingga anoda cendrung melepas elektron dan katoda menangkap electron (Schmidt et al., 2007), 4) elektron bergerak dari katoda ke anoda, seharusnya elektron mengalir dari yang lemah ke yang kuat daya tariknya. Kedua, saat menentukan harga potensial sel dari suatu rangkaian sel volta, terdapat siswa yang menjumlahkan potensial reduksi standar pada masing-masing elektroda. Selain itu, ada siswa yang beranggapan ketika kedua elektroda memiliki harga potensial reduksi standar bernilai negatif, maka tidak terjadi reaksi spontan (Asnawi et al., 2017; Sanger \& Greenbowe, 1997a). Ketiga, fungsi dari komponen yang terdapat dalam sel volta salah satunya jembatan garam terjadi miskonsepsi yaitu jembatan garam berfungsi untuk menyuplai elektron, seharusnya jembatan garam berfungsi untuk menghubungkan kedua larutan elektrolit dan mencegah terjadinya penumpukan muatan positif pada anoda dan muatan negatif pada katoda sehingga kerja sel volta tidak terganggu (Dindar et al., 2010).

Miskonsepsi pada sub topik korosi berkaitan mengenai faktor yang menyebabkan terjadinya korosi dan usaha untuk pencegahan korosi (Asih et al., 2020). Contohnya pada suatu percobaan pencegahan korosi, siswa beranggapan bahwa paku selalu bertindak sebagai katoda, sedangkan logam lainnya bertindak sebagai anoda sehingga logam lain akan teroksidasi karena harga potensial reduksi standarnya lebih kecil dibandingkan paku. Kemudian pada proses korosi akan cepat berlangsung apabila berkontak langsung dengan oksigen atau oksigen yang larut dalam air (Asih et al., 2020), namun proses korosi akan lebih cepat berlangsung apabila tetesan mengandung asam (Syukri, 1999). Selanjutnya pada sub materi elektrolisis, miskonsepsi yang teridentifikasi berkaitan dengan penentuan anoda dan katoda pada sel elektrolisis, jenis elektroda yang digunakan, produk yang dihasilkan dari proses elektrolisis (Hukum Faraday I dan II), serta jenis elektrolit yang digunakan (larutan/ lelehan) (Asnawi et al., 2017; Bakar \& Mukhtar, 2011). Kesalahan konsep yang terjadi diantaranya, 1) siswa menganggap bahwa proses yang terjadi pada sel elektrolisis adalah kebalikan dari sel volta, dimana oksidasi terjadi pada katoda dan oksidasi terjadi pada anoda(Acar \& Tarhan, 2007; Pamela J. Garnett \& Treagust, 1992). Seharusnya elektroda yang bertindak sebagai anoda dan katoda sama halnya dengan sel volta, yang membedakan sel volta dan elektrolisis adalah sel elektrolisis membutuhkan energi listrik untuk memompa elektron sedangkan sel volta tidak membutuhkan energi listrik untuk memompa electron (Syukri, 1999), 2) jenis elektrolit yang digunakan dapat berupa larutan dan lelehan, siswa mengalami kesalahpahaman konsep seperti selama elektrolisis larutan, air tidak ikut bereaksi padahal saat elektrolisis larutan terjadi persaingan antara katoda/ anion dengan air elektrolisis (Sanger \& Greenbowe, 1997b), 3) 
elektrolisis pada leburan garam air akan ikut bereaksi (Asnawi et al., 2017; Bakar \& Mukhtar, 2011), padahal leburan sendiri merupakan senyawa ion yang berwujud padat namun dipanaskan terlebih dahulu hingga meleleh dan terurai menjadi ion-ionnya (Syukri, 1999), 4) jumlah massa zat yang dihasilkan pada katoda akan berbanding terbalik dengan arus listrik yang digunakan (Dewata, 2016), hal ini tidak sesuai dengan hukum faraday I yang berbunyi “ jumlah zat yang tereduksi dan teroksidasi pada elektroda berbanding lurus dengan jumlah arus yang mengalir dalam sel (Syukri, 1999), 5) pada sel elektrolisis larutan dan lelehan diperoleh produk yang sama (Bong \& Lee, 2016), ini merupakan kesalahan konsep dimana hasil pada elektrolisis larutan dan lelehan akan berbeda, karena zat yang ikut bereaksi pada katoda dan anoda pada elektrolisis larutan dan lelehan berbeda (Chang, 2005).

Miskonsepsi yang terjadi pada siswa dapat mempengaruhi hasil belajar karena tidak tercapainya tujuan pembelajaran sehingga dapat menurunkan kualitas pendidikan (Tayubi, 2005). Oleh karena itu, miskonsepsi yang telah teridentifikasi diatas dapat dijadikan sebagai acuan bagi guru untuk merencanakan strategi pembelajaran kedepannya agar meminimalisir terjadinya kesalahpahaman konsep sehingga tidak menghambat siswa untuk menerima pengetahuan pengetahuan baru dalam proses belajar selanjutnya dan sumber informasi ketika melakukan remedial sehingga guru dapat memperbaiki konsep yang salah menjadi benar. Berdasarkan hasil penelitian studi literatur yang peneliti lakukan, ada beberapa keterbatasan yang dialami dan dapat disempurnakan oleh peneliti yang akan datang diantaranya miskonsepsi miskonsepsi yang terjadi pada topik redoks dan elektrokimia belum diselidiki yang menjadi sumber dan faktor penyebab terjadinya miskonsepsi pada materi redoks dan elektrokimia.

\section{KESIMPULAN}

Kesalahan yang terjadi pada siswa dalam memahami suatu konsep yang tidak sesuai secara ilmiah disebut dengan miskonsepsi. Berdasarkan penelitian yang dilakukan oleh beberapa peneliti sebelumnya ditemukan banyak miskonsepsi yang ditemukan pada materi redoks dan elektrokimia yang terdiri dari beberapa sub topik yaitu redoks, sel volta, korosi, dan sel elektrolisis. Miskonsepsi yang terjadi diantaranya pada saat menentukan aliran arus listrik pada sel galvani, potensial sel, elektroda pada sel galvani dan elektrolisis, produk yang dihasilkan pada sel elektrolisis, faktor penyebab terjadinya korosi, pencegahan korosi dan saat menyetarakan persamaan reaksi.

\section{DAFTAR PUSTAKA}

Acar, B., \& Tarhan, L. (2007). on Students ' Understanding of Concepts. International Journal of Science and Mathematics Education, 5, 349-373.

Al-balushi, S. M., Ambusaidi, A. K., Al-shuaili, A. H., \& Taylor, N. (2012). Omani twelfth grade students most common misconceptions in chemistry. Science Education International, 23(3), 221-240.

Artiawati, P. R., Muliyani, R., Kurniawan, Y., \& Guess, L. (2018). Identifikasi K Uantitas S Iswa Yang M Iskonsepsi Menggunakan T Hree T Ier -T Est P Ada M Ateri G Erak L Urus B Erubah B Eraturan ( Glbb ). Jurnal Ilmu Pendidikan Fisika, 3(1), 5-7.

Asih, F. E., Ibnu, S., Suyono, S., \& Suhadi, S. (2020). Students' Misconceptions on Understanding Corrosion Topic by and without Analogy. 1(Snk), 130-134. https://doi.org/10.2991/snk-19.2019.31

Asnawi, R., Effendy, \& Yahmin. (2017). Kemampuan Berpikir Ilmiah Siswa Dan Miskonsepsi Pada Materi Elektrokimia. Jurnal Ilmu Pendidikan, 23(1), 25-33.

Bakar, B., \& Mukhtar, B. (2011). Problems Faced by Fourth 4 Students in the Melting-Out of Electrolysis Based Learning in Chemistry. Journal of Educational Social Science, 1, 96-120. https://core.ac.uk/download/pdf/11787467.pdf 
1197 Identifikasi Mikonsepsi Siswa Menengah Atas (SMA) Pada Pembelajaran Kimia Materi Redoks dan Elektrokimia : Studi Literatur - Nindy Aulia Nisa, Zonalia Fitriza

DOI: https://doi.org/10.31004/edukatif.v3i4.516

Bong, A. Y. L., \& Lee, T. T. (2016). Form four students' misconceptions in electrolysis of molten compounds and aqueous solutions. Asia-Pacific Forum on Science Learning and Teaching, 17(1).

Chang, R. (2005). Kimia Dasar (Konsep kon). Erlangga.

Dewata, I. (2016). Analisis Proses Pembelajaran Pokok Bahasan Elektrokimia Di Kelas Xii Sman 1 Panti. Ta'dib, 14(1). https://doi.org/10.31958/jt.v14i1.195

Dindar, a, Bektaş, O., \& ÇELIK, A. Y. (2010). What are the Pre-service Chemistry Teachers' Explanations on Chemistry Topics? The International Journal of Research in Teacher Education, 1(5), 32-41.

Fitriza, Z., Aini, F. Q., Handayani, P., \& Munira, I. (2020). Development of structured essay diagnostic test of chemistry (SEDToC) to investigate senior high school student's conception of buffer solution. AIP Conference Proceedings, 2229. https://doi.org/10.1063/5.0003289

Fowler, T. W., \& Bou Jaoude, S. (1987). Using hierarchical concept/proposition maps to plan instruction that addresses existing and potential student misunderstandings in science. Proceedings of the Second International Seminar on Misconceptions and Educational Strategies in Science and Mathematics, (Vol. 1, $p$ (haca: Cornell University, Department of Education.).

Garnett, P. J. (2014). Chemistry Misconceptions at the Secondary-Tertiary Interface. January 1993.

Garnett, P. J., Garnett, P. J., \& Hackling, M. W. (1995). Students' alternative conceptions in chemistry: A review of research and implications for teaching and learning. Studies in Science Education, 25(1), 6996. https://doi.org/10.1080/03057269508560050

Garnett, P. J., \& Treagust, D. F. (1992). Conceptual difficulties experienced by senior high school students of electrochemistry: Electrochemical (galvanic) and electrolytic cells. Journal of Research in Science Teaching, 29(10), 1079-1099. https://doi.org/10.1002/tea.3660291006

Hosnan. (2014). Pendekatan Saintifik dan Kontekstual dalam Pembelajaran Abad 21. Ghalia Indonesia.

Huddle, P., \& White, M. (2000). Misconceptions in Electrochemistry Education. Chemical Education Research, 77(1), 104-110.

Kemendikbud. (2014). Konsep dan Implementasi Kurikulum 2013. Kementrian Pendidikan dan Kebudayaan.

Kristiana, E., Sidauruk, S., \& Meiliawati, R. (2020). Kesulitan Siswa Kelas X MIA SMA Negeri Di Kota Palangka Raya Tahun Ajaran 2018/2019 Dalam Memahami Konsep Struktur Lewis Menggunakan Instrumen Two-Tier Multiple Choice. Jurnal Ilmiah Kanderang Tingang, 11(1), 200-208. https://doi.org/10.37304/jikt.v11i1.87

Mestika, Z. (2004). Metode Penelitian Kepustakaan. Yayasan Bogor Indonesia.

Mohd Nor, B., \& Tay, C. (2010). Masalah Pembelajaran Pelajar Tingkatan Empat Dalam Mata Pelajaran Kimia Khususnya Tajuk Elektrokimia. ... Pelajar Tingkatan Empat Dalam Mata Pelajaran .... http://eprints.utm.my/11624/

Ogude, A. N., \& Bradley, J. D. (1994). Ionic Conduction and Electrical Neutrality in Operating Electrochemical Cells. Journal of Chemical Education, 71(1), 29-34.

Ogude, N. A., \& Bradley, J. D. (1996). Electrode Processes and Aspects Relating to Cell EMF, Current, and Cell Components in Operating Electrochemical Cells. Journal of Chemical Education, 73(12), 11451149.

Özkaya, A. L. İ., Üce, M. U. S. A., \& Şahin, M. (2003). Prospective teachers' conceptual understanding of electrochemistry.

Rahayu, S., Treagust, D. F., Chandrasegaran, A. L., Kita, M., \& Ibnua, S. (2011). Assessment of electrochemical concepts: A comparative study involving senior high-school students in Indonesia and Japan. Research in Science and Technological Education, 29(2), 169-188. https://doi.org/10.1080/02635143.2010.536949 
1198 Identifikasi Mikonsepsi Siswa Menengah Atas (SMA) Pada Pembelajaran Kimia Materi Redoks dan Elektrokimia : Studi Literatur - Nindy Aulia Nisa, Zonalia Fitriza

DOI: https://doi.org/10.31004/edukatif.v3i4.516

Sanger, M. J., \& Greenbowe, T. J. (1997a). Common Student Misconceptions in Electrochemistry: Galvanic, Electrolytic, and Concentration Cells. Journal of Research in Science Teaching, 34(4), 377-398. https://doi.org/10.1002/(SICI)1098-2736(199704)34:4<377::AID-TEA7>3.0.CO;2-O

Sanger, M. J., \& Greenbowe, T. J. (1997b). Students' misconceptions in electrochemistry: Current flow in electrolyte solutions and the salt bridge. Journal of Chemical Education, 74(7), 819-823. https://doi.org/10.1021/ed074p819

Schmidt, H. J., Marohn, A., \& Harrison, A. G. (2007). Factors that prevent learning in electrochemistry. Journal of Research in Science Teaching, 44(2), 258-283. https://doi.org/10.1002/tea.20118

Snyder, H. (2019). Literature review as a research methodology: An overview and guidelines. Journal of Business Research, 104(August), 333-339. https://doi.org/10.1016/j.jbusres.2019.07.039

Syukri. (1999). Kimia Dasar 3. Penerbit ITB.

Tayubi, Y. R. (2005). Identifikasi Miskonsepsi pada Konsep-Konsep Fisika Menggunakan Certainty of Response Index (CRI). Jurnal UPI, 24(3), 4-9.

Treagust, D. F. (2006). Diagnostic assesment in Science as a means to improving teaching, learning and retention. Uni Serve Science Assesement http://www.tamu.edu/mars/assess/HTMLfiles/oabooks.html

Yulianingtyas, E., Budiasih, E., \& Marfuah, S. (2017). Pengaruh Penggunaan Jurnal Belajar Dalam Model Pembelajaran Learning Cycle 6E Terhadap Kesadaran Metakognitif Siswa Sman 8 Malang Pada Materi Redoks. Teori, Penelitian, Dan Pengembangan, 2(5), 724-730. http://journal.um.ac.id/index.php/jptpp/ 